\title{
Estimated crop yield losses due to surface ozone exposure and economic damage in India
}

\author{
S. B. Debaje
}

Received: 28 May 2013 / Accepted: 12 January 2014 / Published online: 28 February 2014

(C) The Author(s) 2014. This article is published with open access at Springerlink.com

\begin{abstract}
In this study, we estimate yield losses and economic damage of two major crops (winter wheat and rabi rice) due to surface ozone $\left(\mathrm{O}_{3}\right)$ exposure using hourly $\mathrm{O}_{3}$ concentrations for the period 2002-2007 in India. This study estimates crop yield losses according to two indices of $\mathrm{O}_{3}$ exposure: 7-h seasonal daytime (0900-1600 hours) mean measured $\mathrm{O}_{3}$ concentration (M7) and AOT40 (accumulation exposure of $\mathrm{O}_{3}$ concentration over a threshold of 40 parts per billion by volume during daylight hours (0700-1800 hours), established by field studies. Our results indicate that relative yield loss from 5 to $11 \%(6-30 \%)$ for winter wheat and 3-6\% (9-16\%) for rabi rice using M7 (AOT40) index of the mean total winter wheat 81 million metric tons $(\mathrm{Mt})$ and rabi rice $12 \mathrm{Mt}$ production per year for the period 2002-2007. The estimated mean crop production loss (CPL) for winter wheat are from 9 to $29 \mathrm{Mt}$, account for economic cost loss was from 1,222 to 4,091 million US\$ annually. Similarly, the mean CPL for rabi rice are from 0.64 to $2.1 \mathrm{Mt}$, worth 86-276 million US\$. Our calculated winter wheat and rabi rice losses agree well with previous results, providing the further evidence that large crop yield losses occurring in India due to current $\mathrm{O}_{3}$ concentration and further elevated $\mathrm{O}_{3}$ concentration in future may pose threat to food security.
\end{abstract}

Keywords Air pollution impacts $\cdot$ Surface ozone $\cdot$ Crop yield losses · Economical losses · Food security $\cdot$ Atmospheric condition

Responsible editor: Philippe Garrigues

S. B. Debaje $(\bowtie)$

Indian Institute of Tropical Meteorology, Dr. Homi Bhabha

RoadPashan Pune 411008, India

e-mail: debaje@tropmet.res.in

\section{Introduction}

Surface ozone $\left(\mathrm{O}_{3}\right)$ is a secondary air pollutant, despite its detrimental effects on human health, field experiments has demonstrated that the $\mathrm{O}_{3}$ causes substantial damage to plant and agricultural crops (Amann et al. 2008; Fuhrer 2009). Exposure of high $\mathrm{O}_{3}$ concentration greater than 40 parts per billion by volume (ppbv) causes large yield losses of many agriculture crops (Fuhrer and Ashmore 1997). Over $90 \%$ of vegetation is damaged due to $\mathrm{O}_{3}$ exposure alone (Felzer et al. 2007). Several field experiments studies in the USA, Europe, and Asia have demonstrated that the $\mathrm{O}_{3}$ is responsible for more damage to vegetation and agricultural crops than any other air pollutant (Mauzerall and Wang 2001; Mittal et al. 2007; Engardt 2008; Ghude et al. 2008; The Royal Society 2008; Booker et al. 2009; Emberson et al. 2009; Zhu et al. 2011; Wilkinson et al. 2012; Tang et al. 2013; Elampari et al. 2013 and references therein). Field experiment studies in the USA (National Crop Loss Assessment Network, NCLAN) and in Europe (European Open Top Chambers Programme, EOTCP) showed that crops yield losses occur by $5-10 \%$ and deteriorating a crop quality and larger losses are expected in the future. Relatively less number of experimental studies has been conducted in Asia and in developing countries compared to in the USA and in Europe. However, a few experimental and modeling studies have been performed demonstrating that crops yield losses occurring due to $\mathrm{O}_{3}$ exposure in Asia and in particular in India and Pakistan (Agrawal 2003; Wahid 2003; Wang and Mauzerall 2004). The winter wheat losses estimated greater than $10 \%$ due to high $\mathrm{O}_{3}$ levels ( $\left.>60 \mathrm{ppbv}\right)$ in southern China using an atmospheric chemistry model along with a regional climate model (Chameides et al. 1999). In the Indian subcontinent, studies performed by Agrawal (2003), Wahid (2003), and Debaje et al. (2010) documented that 
winter wheat yield losses by $5-43 \%$ due to $\mathrm{O}_{3}$ exposure in winter season. The $\mathrm{O}_{3}$-induced agriculture losses are two to three times larger than estimated crop losses due to climate change that highlights the development of crop cultivars with $\mathrm{O}_{3}$-resistance are beneficial in future (Lobell and Field 2007).

Global studies relating to $\mathrm{O}_{3}$-induced crop yield losses has shown that relative yield loss (RYL), crop production loss (CPL), and associated economic cost losses (ECL) highest in India followed by in China (Van Dingenen et al. 2009; Avnery et al. 2011a). Van Dingenen et al. (2009) reported that highest wheat and rice losses in India due to $\mathrm{O}_{3}$ damage using M7 and AOT40 indices. Similarly, Avnery et al. (2011a) reported that highest wheat losses in India from M7 and AOT40 indices due to $\mathrm{O}_{3}$ damage. To our knowledge, only the two studies are reported $\mathrm{O}_{3}$-induced crop yield losses on a global scale, highlighting that the highest winter wheat and rice losses in India. China, Japan, and South Korea are also experiencing similar wheat and rice losses on large scale in Asian region by $\mathrm{O}_{3}$ damage due to increase of $\mathrm{O}_{3}$ concentration (Wang and Mauzerall 2004; Wang et al. 2012).

We use M7 and AOT40 indices to estimate winter wheat and rabi rice crop yield losses using $\mathrm{O}_{3}$ data available in India. The $\mathrm{M} 7$ index is the seasonal daylight mean $\mathrm{O}_{3}$ concentration for the $7 \mathrm{~h}$ mean (09-16 hours) and AOT40 (accumulation exposure of $\mathrm{O}_{3}$ concentration over a threshold of $40 \mathrm{ppbv}$ during daylight hours, $07-18$ hours) index for 3-month period from growing to harvesting season of crop. In India, winter wheat is mainly cultivated from December to March during the winter season. Further, rice is grown in two major seasons, kharif (June-October) and rabi (October-February) (NCS 2013). Most of the rice area (39.3 million ha) and production are in the kharif season ( $86 \%$ of the total rice production). However, the productivity of kharif rice is lower $2,985 \mathrm{~kg} \mathrm{ha}^{-1}$ than the rabi rice productivity $4,691 \mathrm{~kg} \mathrm{ha}^{-1}$. The highest area under rabi rice cultivation is 1.5 and 1.4 million ha in Andhra Pradesh and in West Bengal, respectively, of the total area 4.3 million ha.

The photochemical production of $\mathrm{O}_{3}$ is controlled by oxides of nitrogen $\left(\mathrm{NO}_{\mathrm{x}}\right)$ in India implies that $\mathrm{O}_{3}$ concentration increases with increase of $\mathrm{NO}_{\mathrm{x}}$ concentration (Berntsen et al. 1996; van Aardenne et al. 1999; Lelieveld et al. 2001). The daytime maximum of $\mathrm{O}_{3}$ concentrations is less than $40 \mathrm{ppbv}$ during the kharif rice season help sparing from $\mathrm{O}_{3}$ damage because of south west (SW) monsoon rains (June-September; IMD 2007; http://www.imd.gov.in). Rice is moderately sensitive to $\mathrm{O}_{3}$; its AOT40 critical limit is $12.8 \mathrm{ppm} \mathrm{h}$, while winter wheat is sensitive to $\mathrm{O}_{3}$; its AOT40 critical limit is 3 . $3 \mathrm{ppm} \mathrm{h}$ for $5 \%$ yield losses (Mill et al. 2007). In this study, therefore, our analysis is on rabi rice losses when daytime maximum of $\mathrm{O}_{3}$ concentration greater than $40 \mathrm{ppbv}$. The production of kharif crops (particularly kharif rice) totally depends on the SW monsoon rains which are highly erratic in nature (DRD 2007). In this study, we present mean RYL, CPL, and associated ECL are occurred for two major staple crops winter wheat and rabi rice due to $\mathrm{O}_{3}$ pollution for five crop years for the period 2002-2007 (study period) using $\mathrm{O}_{3}$ exposure yield response indices M7 and AOT40 calculated first time from measured hourly $\mathrm{O}_{3}$ concentrations available data over the Indian region.

\section{Materials and methods}

We estimate winter wheat and rabi rice yield losses using $\mathrm{O}_{3}$ exposure indices M7 and AOT40 for the study period, except for the period 2008-2009 (Singla et al. 2011) and 2009-2011 (Mahapatra et al. 2012) as $\mathrm{O}_{3}$ studies are not available at these sites from 2002 to 2007 (Table 1). M7 index is calculated for all the available sites using monthly diurnal variation of $\mathrm{O}_{3}$ for $7 \mathrm{~h}$ mean from 0900 to 1600 hours daylight for a 3-month period from sowing to harvesting "growing season" of the crop. Winter wheat is grown between the months midNovember to April, while rabi rice grown from NovemberFebruary to March-June. Average M7 index values vary between 49.5 and 68 ppbv over the Indian region. The reference concentration of $\mathrm{O}_{3}$ is $25 \mathrm{ppbv}$ in the calculation of $\mathrm{M} 7$ index. AOT40 index is calculated from M7 index values obtained from measured $\mathrm{O}_{3}$ concentration and the relationship between 3-month AOT40 (parts per million hours, ppm h) and 3-month 7-h mean $\mathrm{O}_{3}$ (ppbv) provided by Mills et al. (2007; Table 2).

Seasonal $\mathrm{O}_{3}$ mean of M7 and AOT40 indices are derived for winter wheat from January to March, and for rabi rice from December to February. Potential grain yield is primarily determined before heading, but actual yield, which is based on the amount of starch that ultimately fills the spikelet's, is largely determined after heading (NCS 2013). Hence, we calculate $\mathrm{O}_{3}$ exposure yield response $\mathrm{M} 7$ index for last 3 months of the winter wheat (January-March) and rabi rice (December-February) crop. We select the top ten states which are major producers of winter wheat and rabi rice for assessing impact of $\mathrm{O}_{3}$ exposure according to the M7 and AOT40 indices (http://dwd.dacnet.nic.in/wheat_prod1/index.htm and http://drd.dacnet.nic.in/Downloads/Handbook-of-Statistics2007.pdf) (DRD 2007).

\section{$\mathrm{O}_{3}$ exposure and $\mathrm{CR}$ relationships}

The $\mathrm{O}_{3}$ indices are derived from open-top chamber (OTC) field studies conducted in the USA and Europe have established crop-specific crop response (CR) functions that 
Table 1 Winter wheat and rabi rice crop yield losses are based on M7 and AOT40 indices of hourly surface ozone $\left(\mathrm{O}_{3}\right)$ concentration (parts per billion by volume) during daylight hours measurements available data after the year 2000 in India

\begin{tabular}{|c|c|c|c|c|c|}
\hline Site/State & Latitude Longitude & Altitude (m) & Period & $\mathrm{O}_{3}(\mathrm{ppbv})^{\mathrm{a}}$ & Reference \\
\hline \multicolumn{6}{|c|}{ Northern India $\left(21-35^{\circ} \mathrm{N}, 68-90^{\circ} \mathrm{E}\right)$} \\
\hline Nainital, UC & $29.4^{\circ} \mathrm{N} 79.5^{\circ} \mathrm{E}$ & 1958 & $2006-2008$ & $42 \pm 6$ to $57 \pm 11$ & Kumar et al. (2010) \\
\hline Delhi, Delhi & $28.4^{\circ} \mathrm{N} 77.5^{\circ} \mathrm{E}$ & 216 & 1997-2004 & $50 \pm 15$ to $95 \pm 22$ & Jain et al. (2005) \\
\hline Agra, UP & $27.2^{\circ} \mathrm{N} 78^{\circ} \mathrm{E}$ & 169 & 2008-2009 & $55 \pm 7$ to $65 \pm 11$ & Singla et al. (2011) \\
\hline Agra, UP & $27.2^{\circ} \mathrm{N} 78^{\circ} \mathrm{E}$ & 169 & $2000-2002$ & $56 \pm 3$ to $63 \pm 5$ & Satsangi et al. (2004) \\
\hline Kolkata, WB & $22^{\circ} \mathrm{N} 88^{\circ} \mathrm{E}$ & 5 & 2003-2004 & $25 \pm 5$ to $35 \pm 7$ & Purkait et al. (2009) \\
\hline Bhubaneswar, OR & $21.3^{\circ} \mathrm{N} 85.3^{\circ} \mathrm{E}$ & 45 & 2009-2011 & $50 \pm 15$ to $78 \pm 23$ & Mahapatra et al. (2012) \\
\hline \multicolumn{6}{|c|}{ Southern India $\left(5-20^{\circ} \mathrm{N}, 68-90^{\circ} \mathrm{E}\right)$} \\
\hline Joharapur, MH & $19.3^{\circ} \mathrm{N} 75.2^{\circ} \mathrm{E}$ & 474 & $2002-2005$ & $53 \pm 17$ to $55 \pm 11$ & Debaje and Kakade (2009) \\
\hline Ahmednagar, $\mathrm{MH}$ & $19.1^{\circ} \mathrm{N} 74.8^{\circ} \mathrm{E}$ & 657 & 2006-2007 & $42 \pm 12$ to $57 \pm 15$ & Debaje et al. (2010) \\
\hline Pune, $\mathrm{MH}$ & $18.5^{\circ} \mathrm{N} 73.8^{\circ} \mathrm{E}$ & 559 & 2003-2004 & $34 \pm 20$ to $55 \pm 25$ & Beig et al. (2007) \\
\hline Pune, MH & $18.5^{\circ} \mathrm{N} 73.8^{\circ} \mathrm{E}$ & 559 & 2001-2005 & $48 \pm 7$ to $50 \pm 6$ & Debaje and Kakade (2009) \\
\hline Anantapur, AP & $14.6^{\circ} \mathrm{N} 77.6^{\circ} \mathrm{E}$ & 331 & $2002-2003$ & $47 \pm 6$ to $49 \pm 8$ & Reddy et al. (2008) \\
\hline Anantapur, AP & $14.6^{\circ} \mathrm{N} 77.6^{\circ} \mathrm{E}$ & 331 & 2001-2003 & $48 \pm 6$ to $56 \pm 8$ & Ahammed et al. (2006) \\
\hline Trivandrum, KR & $8.6^{\circ} \mathrm{N} 77^{\circ} \mathrm{E}$ & 2 & 2007-2009 & $25 \pm 5$ to $45 \pm 10$ & David and Nair (2011) \\
\hline
\end{tabular}

UC Uttaranchal, UP Uttar Pradesh, WB West Bengal, OR Orissa, $M H$ Maharashtra, AP Andhra Pradesh, KR Kerala

${ }^{\text {a }}$ Monthly average $\mathrm{O}_{3}$ concentration from December to March

used to predict the yield response of a crop to a given concentration of $\mathrm{O}_{3}$ exposure. We use M7 and AOT40 exposurebased indices and its $\mathrm{CR}$ relationships to calculate RYL of winter wheat and rabi rice shown in Table 2.

Winter wheat and rabi rice RYL is translated into CPL using mean production of winter wheat and rabi rice:

$\mathrm{CPL}=\frac{\mathrm{RYL}}{1-\mathrm{RYL}} \times$ production $_{2002-2007}$

Winter wheat and rabi rice CPL is converted into ECL based on the mean minimum support price (MSP) for the five crops years (CACP 2012). The MSP for wheat and rice is 142.05 and 134 US\$ per ton, respectively $(1 \mathrm{t}=1,000 \mathrm{~kg}, 1$ US $\$=44.49$ Indian Rupees) fixed by the Government of India each year (http://agricoop.nic.in/Agristatistics.htm, http:// cacp.dacnet.nic.in/Rpp/kharif Report 2012-13.pdf). The ECL is calculated as follows:

$\mathrm{ECL}=\mathrm{CPL} \times \mathrm{MSP}_{2002-2007}$

MSP is approximately $50 \%$ less than the market price.

\section{Results}

RYL of winter wheat and rabi rice

Figure 1 illustrates the winter wheat RYL (in percent) in the top ten states (Uttar Pradesh, Punjab, Haryana, Madhya

Table 2 Air quality indices used to evaluate the winter wheat and rabi rice crop yield losses over India. All surface ozone $\left(\mathrm{O}_{3}\right)$ concentration $($ parts per billion by volume) refers to hourly values

\begin{tabular}{|c|c|c|c|c|c|c|c|c|}
\hline \multirow[t]{2}{*}{ Index } & \multirow[t]{2}{*}{ Unit } & \multirow[t]{2}{*}{ Definition } & \multirow{2}{*}{$\begin{array}{l}\text { Exposure/dose response function: } \\
\text { relative yield loss (RYL) }\end{array}$} & \multicolumn{2}{|l|}{ Wheat } & \multicolumn{2}{|l|}{ Rice } & \multirow[t]{2}{*}{ Reference } \\
\hline & & & & $\mathrm{a}$ & $\mathrm{b}$ & $\mathrm{a}$ & $\mathrm{b}$ & \\
\hline M7 & ppbv & $\begin{array}{l}\text { 7-h seasonal } \mathrm{O}_{3} \text { mean } 3 \text { months, } \\
09-16 \mathrm{~h}\end{array}$ & $1-\exp \left[-(M 7 / a)^{b}\right] / \exp \left[-(25 / a)^{b}\right]$ & 137 & 2.34 & 202 & 2.47 & Wang and Mauzerall (2004) \\
\hline AOT40 & ppm h & $\begin{array}{l}(\mathrm{M} 7-29) / 1.59 \\
3 \text { months }\end{array}$ & aAOT40 & 0.0161 & 0.99 & 0.00415 & 0.94 & $\begin{array}{l}\text { Mills et al. (2007) } \\
\text { Van Dingenen et al. (2009) }\end{array}$ \\
\hline
\end{tabular}

AOT40 $=\sum_{i=1}^{n}\left[\mathrm{O}_{3}\right]_{i}-40,\left[\mathrm{O}_{3}\right]>40$ ppbv; during daylight $\left(0700-1800\right.$ hours; $\left[\mathrm{O}_{3}\right]=$ hourly averaged $\mathrm{O}_{3}$ concentration in parts per billion by volume; $40=$ threshold limit of $\mathrm{O}_{3}$ and $n$ is the number of hours from growing to harvesting season of crop

3 months January, February, and March for wheat; December, January, and February for rice 
Pradesh, Rajasthan, Bihar, Maharashtra, Gujarat, West Bengal, and Uttaranchal) in India's map due to $\mathrm{O}_{3}$ exposure according to the M7 and AOT40 indices per year for the study period (shaded areas). The production of winter wheat is low in the remaining states (unshaded areas). The winter wheat RYL is ranged between 5 and $11 \%$ (6 and $30 \%)$ using M7 (AOT40) index. The highest winter wheat RYL from 9 to $11 \%$ (26-30 \%) using M7 (AOT40) index is in Punjab, Haryana, Rajasthan, Uttaranchal, Uttar Pradesh, Bihar, and Madhya Pradesh in the Indo-Gangetic plain of India which is the most agriculture fertile region. All these states in northern India are experiencing high $\mathrm{O}_{3}$ concentration $(>80 \mathrm{ppbv})$ during winter and summer season due to high emission of $\mathrm{NO}_{\mathrm{x}}$ and favorable atmospheric conditions for photochemical $\mathrm{O}_{3}$ formation (van Aardenne et al. 1999; Ohara et al. 2007). The low winter wheat RYL 5-8 \% (6-24\%) using M7 (AOT40) index was in Maharashtra, West Bengal, and Gujarat due to low $\mathrm{O}_{3}$ concentration. We calculate the average winter wheat RYL is 9\% (21\%) using the M7 (AOT40) index for the Indian region. Winter wheat crop is especially sensitive to $\mathrm{O}_{3}$ in India due to the likely co-occurrence of peak levels of $\mathrm{O}_{3}$ and growing season (Emberson et al. 2003; Jain et al. 2005). The latitudinal variations of $\mathrm{O}_{3}$ concentration over the India show the higher $\mathrm{O}_{3}$ in northern India than in southern India (Carmichael et al. 2003; Table 1).

Similarly, Fig. 2 illustrates the rabi rice RYL in the top ten states (West Bengal, Andhra Pradesh, Karnataka, Orissa, Assam, Tamil Nadu, Bihar, Kerala, Maharashtra, and Uttar Pradesh) due to $\mathrm{O}_{3}$ exposure according to the $\mathrm{M} 7$ and AOT40 indices (shaded areas). The production of rabi rice is low in the remaining states (unshaded areas). The rabi rice RYL ranged between 3 and $6 \%$ (12 and $16 \%$ ) using the M7 (AOT40) index. The highest rabi rice RYL is $6 \%(16 \%)$ using M7 (AOT40) index in Andhra Pradesh and Karnataka in the southern India, while the lowest rabi rice RYL is $3 \%(12 \%)$ in Kerala and Tamil Nadu in the southern tip of India. The average rabi rice RYL is $5 \%$ (14\%) using M7 (AOT40) index for the Indian region.

Winter wheat losses and associated monetary loss

Table 3 presents the mean winter wheat production and winter wheat losses (RYL, CPL, and ECL) estimated in the top ten states per year using M7 and AOT40 indices for the study period. The production of winter wheat in other states in India is low and it is shown as others (16 states) in Table 3. The highest winter wheat production is 27 million metric tons (Mt) occurred in Uttar Pradesh followed by in Punjab 17 Mt and Haryana $10 \mathrm{Mt}$ account for nearly $70 \%$ of the total winter wheat production is $81 \mathrm{Mt}$ per year. However, the highest yield of winter wheat is $5,513 \mathrm{~kg} / \mathrm{ha}$ in Punjab, $4,947 \mathrm{~kg} / \mathrm{ha}$ in Haryana, and 3,275 kg/ha in Uttar Pradesh. The winter wheat production was only $10 \mathrm{Mt}(12 \%)$ from Bihar, Maharashtra,
Gujarat, West Bengal, and Uttaranchal of the total winter wheat production because of low yield (1,594-2,791 kg/ha). Table 3 also shows the winter wheat losses estimated using M7 and AOT40 indices. The higher winter wheat RYL is $5 \mathrm{Mt}$ $(15 \mathrm{Mt})$ in top three states of the total winter wheat RYL $8 \mathrm{Mt}$ (22 Mt) per year than in the remaining states using M7 (AOT40) index. The mean total winter wheat RYL is $8 \mathrm{Mt}$ (22 Mt) account for 10\% (27\%) losses using M7 (AOT40) index of the total winter wheat productions in these three states. Winter wheat CPL is calculated using winter wheat RYL and winter wheat production by Eq. (1). The highest winter wheat CPL $3 \mathrm{Mt}(9 \mathrm{Mt})$ occurred in Uttar Pradesh followed by $2 \mathrm{Mt}(7 \mathrm{Mt})$ and $1 \mathrm{Mt}$ (4 Mt) in Punjab and Haryana, respectively, of the total winter wheat CPL $9 \mathrm{Mt}$ (29 Mt) per year using M7 (AOT40) index. Using the AOT40 index, winter wheat CPL is $20 \mathrm{Mt}(70 \%)$ in top three states of the total winter wheat CPL $29 \mathrm{Mt}$. The highest winter wheat CPL is $17 \mathrm{Mt}(\sim 60 \%)$ in Utter Pradesh and Punjab together of the total winter wheat CPL. The associated winter wheat ECL is calculated using winter wheat CPL and winter wheat MSP by Eq. (2). The highest winter wheat ECL is 841 million US\$ (2,885 million US\$) of the total winter wheat ECL 1,222 million US\$ (4,091 million US\$) using M7 (AOT40) index in the top three states annually.

The top three states Uttar Pradesh, Punjab, and Haryana contribute the highest winter wheat CPL $6 \mathrm{Mt}(20 \mathrm{Mt})$ of the total winter wheat CPL $9 \mathrm{Mt}(29 \mathrm{Mt})$ using M7 (AOT40) index. Ten states contribute the winter wheat ECL is 1,195 million US\$ $(4,048$ million US\$) of the total winter wheat ECL is 1,222 million US\$ (4,091 million US\$) using the M7 (AOT40) index. The comparison between M7 and AOT40 indices shows the winter wheat ECL is more than three times higher using AOT40 index than the winter wheat ECL using M7 index.

Rabi rice losses and associated monetary loss

Table 4 shows the mean total rice (kharif plus rabi) production and rabi rice losses is estimated in the top ten states per year using the M7 and AOT40 indices for the study period. The production of rice in other states in India is low and it is shown as others (seven states) in Table 4. The state-wise order in Table 4 is as per the rabi rice production. The total mean rice production is $86 \mathrm{Mt}$ per year (production of kharif rice is $74 \mathrm{Mt}$ and rabi rice $12 \mathrm{Mt}$, i.e., $14 \%$ of total rice production). The highest rice production is 15 and $11 \mathrm{Mt}$ in West Bengal and in Uttar Pradesh, respectively. Similarly, the highest rabi rice production is 4.2 Mt in West Bengal and 3.9 Mt in Andhra Pradesh together account for about $70 \%$ of the total rabi rice production. The highest rabi rice $\mathrm{RYL}$ is $0.24 \mathrm{Mt}(0.62 \mathrm{Mt})$ in Andhra Pradesh due to high $\mathrm{O}_{3}$ concentration greater than 55 ppbv followed by in West Bengal is $0.21 \mathrm{Mt}(0.55 \mathrm{Mt})$ of the total rabi rice RYL $0.63 \mathrm{Mt}(1.7 \mathrm{Mt})$ per year using the $\mathrm{M} 7$ 


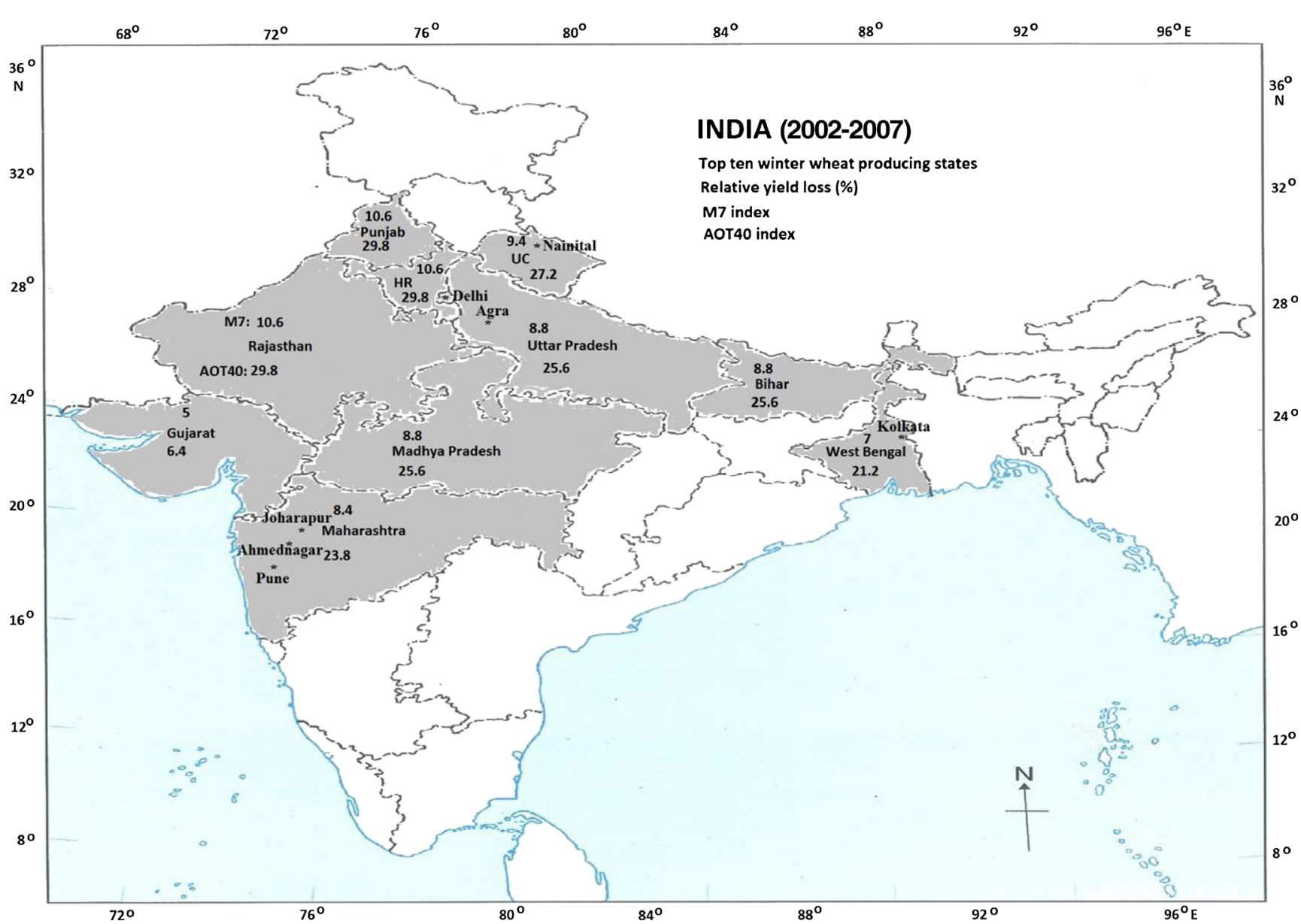

Fig. 1 Map of India shows the winter wheat relative yield loss (in percent) per year in top ten states producing winter wheat for the period 2002-2007 due to $\mathrm{O}_{3}$ exposure according to the $\mathrm{M} 7$ and AOT40 indices.
HR is Haryana state. Top numbers on the states name is RYL using M7 index and bottom number RYL using AOT40 index. Stars the location of $\mathrm{O}_{3}$ measurements site
(AOT40) index. The total rabi rice RYL is $0.63 \mathrm{Mt}(1.7 \mathrm{Mt})$ accounting for $5 \%(14 \%)$ losses using the M7 (AOT40) index per year of the total rabi rice production.

The highest rabi rice CPL is $0.3 \mathrm{Mt}(0.74 \mathrm{Mt})$ in Andhra Pradesh followed by $0.2 \mathrm{Mt}(0.73 \mathrm{Mt})$ in West Bengal of the total CPL 0.64 Mt (2.06 Mt) using the M7 (AOT40) index, and the associated ECL is 34 million US\$ (99 million US\$) and 30 million US\$ (98 million US\$) of the total ECL is 86 million US\$ (276 million US\$) annually. The comparison between M7 and AOT40 indices shows the rabi rice ECL is more than three times higher using the AOT40 index than the rabi rice ECL using the M7 index.

\section{Discussion}

In this study, we estimate winter wheat and rabi rice crop yield losses using the M7 and AOT40 indices in India. The results obtained in this study are compared with previous studies carried out in India and on global scale reveals that our estimate of winter wheat and rabi rice losses due to $\mathrm{O}_{3}$ - induced exposure are in good agreement. The average estimated winter wheat and rabi rice RYL is $9(21 \%)$ and $5 \%$ (14\%), respectively, using the M7 (AOT40) index. The higher winter wheat RYL is $10 \%$ (28\%) over the Indo-Gangetic plain using the M7 (AOT40) index in this study is comparable with the winter wheat RYL reported using the AOT40 index from measured $\mathrm{O}_{3}$ by Ghude et al. (2008). Ghude et al. (2008) and Deb Roy et al. (2009) reported that winter wheat RYL is $23 \%$ over Indo-Gangetic plain in north India. The winter wheat and rabi rice losses estimated in this study is well agree with the winter wheat and summer crop yield losses $1.1-15.6 \%$ is estimated from the $\mathrm{O}_{3}$ concentration using the AOT40 index in earlier studies in India (Mittal et al. 2007; Engardt 2008; Debaje et al. 2010; Elampari et al. 2013). Winter wheat and rabi rice losses estimated in this study is comparable to the grain weights of winter wheat (rice) is decreases from 18.6 to $37.2 \%$ (10.1-17.3\%) with increase of AOT40 values from 23 to $62 \mathrm{ppm} \mathrm{h}(29-83 \mathrm{ppm} \mathrm{h}$ ) in OTC study in China reported by Wang et al. (2012). Recently, Tang et al. (2013) projected using chemical transport model that the RYL of wheat to increase $13.6-30 \%$ for India and 


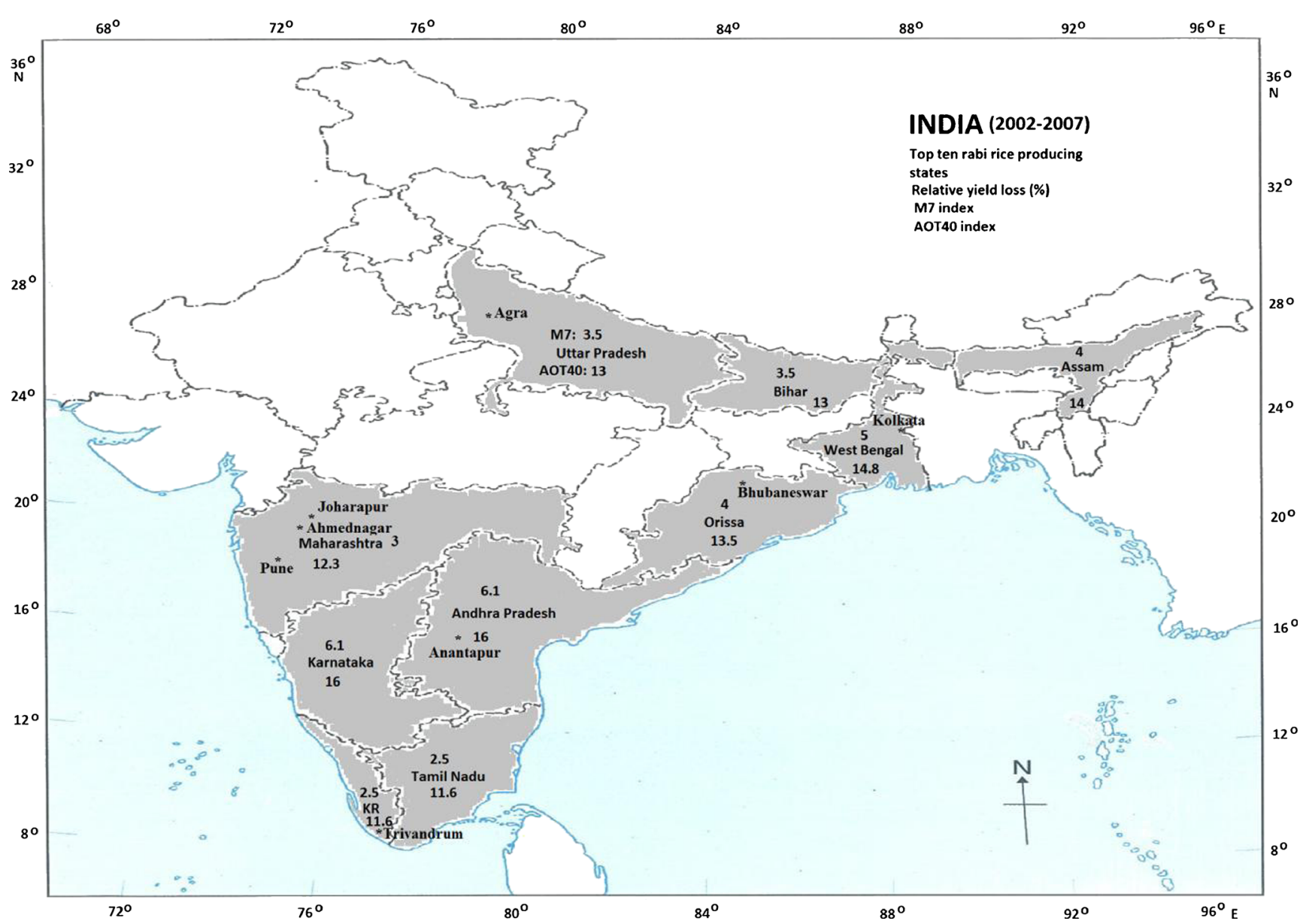

Fig. 2 Map of India shows the rabi rice relative yield loss (in percent) per year in top ten states producing rabi rice for the period $2002-2007$ due to $\mathrm{O}_{3}$ exposure according to the M7 and AOT40 indices. Star mark shows the location of $\mathrm{O}_{3}$ measurements site

$14.5-24.3 \%$ in China based on AOT40 index in 2020. Our estimate of winter wheat and rabi rice losses is in the range of the grain losses projected due to increase $\mathrm{O}_{3}$ concentration using M7 and M12 indices to increase to $2-16 \%$ for wheat
Table 3 Mean winter wheat production (WP) and winter wheat losses (relative yield loss (RYL), crop production loss (CPL) and economic cost loss (ECL)) per year in top ten states in India using M7 and AOT40 indices for the period 2002-2007

WP, RYL and CPL of winter wheat crop are in million metric tons and ECL in million US dollars

\begin{tabular}{|c|c|c|c|c|c|c|c|c|}
\hline \multirow[t]{3}{*}{ State } & \multirow{3}{*}{$\begin{array}{l}\text { Winter wheat } \\
\text { production }\end{array}$} & \multirow[t]{3}{*}{ WP (\%) } & \multicolumn{6}{|c|}{ Winter wheat losses } \\
\hline & & & \multicolumn{3}{|l|}{ M7 } & \multicolumn{3}{|c|}{ AOT40 } \\
\hline & & & RYL & CPL & ECL & RYL & CPL & ECL \\
\hline Uttar Pradesh & 27.36 & 33.7 & 2.41 & 2.64 & 375 & 7 & 9.41 & $1,336.7$ \\
\hline Punjab & 17.24 & 21.2 & 1.83 & 2.04 & 289.8 & 5.14 & 7.3 & 1,037 \\
\hline Haryana & 10.47 & 12.9 & 1.11 & 1.24 & 176.1 & 3.12 & 3.6 & 511.4 \\
\hline Madhya Pradesh & 7.79 & 9.6 & 0.69 & 0.75 & 106.5 & 1.99 & 2.68 & 380.7 \\
\hline Rajasthan & 7.2 & 8.9 & 0.76 & 0.85 & 120.7 & 2.14 & 3.06 & 434.7 \\
\hline Bihar & 5.02 & 6.2 & 0.44 & 0.48 & 68.2 & 1.29 & 1.73 & 245.7 \\
\hline Maharashtra & 1.39 & 1.7 & 0.12 & 0.13 & 18.5 & 0.33 & 0.43 & 61.1 \\
\hline Gujarat & 1.27 & 1.6 & 0.06 & 0.07 & 9.9 & 0.08 & 0.09 & 12.8 \\
\hline West Bengal & 1.009 & 1.2 & 0.07 & 0.08 & 11.4 & 0.21 & 0.27 & 38.3 \\
\hline Uttaranchal & 0.84 & 1 & 0.08 & 0.09 & 12.8 & 0.23 & 0.31 & 44 \\
\hline Others (16 states) & 1.7 & 2 & 0.17 & 0.19 & 27 & 0.25 & 0.3 & 42.6 \\
\hline Total (all India) & 81.27 & 100 & 7.73 & 8.60 & $1,221.6$ & 21.79 & 28.8 & 4,091 \\
\hline
\end{tabular}


Table 4 Mean total rice (kharif plus rabi) production (RP) and rabi rice (RR) losses (relative yield loss (RYL), crop production loss (CPL), and economic cost loss (ECL)) per year in top ten states in India using M7 and AOT40 indices for the period 2002-2007

$\mathrm{RP}$, rabi rice, $\mathrm{RYL}$, and $\mathrm{CPL}$ are in million metric tons and ECL in million US dollars

\begin{tabular}{|c|c|c|c|c|c|c|c|c|c|c|}
\hline \multirow[t]{3}{*}{ State } & \multirow{3}{*}{$\begin{array}{l}\text { Rice } \\
\text { production }\end{array}$} & \multirow{3}{*}{$\begin{array}{l}\text { RP } \\
(\%)\end{array}$} & \multirow{3}{*}{$\begin{array}{l}\text { Rabi rice } \\
\text { production }\end{array}$} & \multirow{3}{*}{$\begin{array}{l}\mathrm{RR} \\
(\%)\end{array}$} & \multicolumn{6}{|c|}{ Rabi rice losses } \\
\hline & & & & & \multicolumn{3}{|l|}{ M7 } & \multicolumn{3}{|c|}{ AOT40 } \\
\hline & & & & & RYL & CPL & ECL & RYL & CPL & ECL \\
\hline West Bengal & 14.89 & 17.4 & 4.22 & 36.1 & 0.21 & 0.22 & 29.8 & 0.55 & 0.73 & 98.1 \\
\hline Andhra Pradesh & 10.06 & 11.8 & 3.88 & 33.3 & 0.24 & 0.25 & 33.8 & 0.62 & 0.74 & 99 \\
\hline Karnataka & 4.05 & 4.7 & 1.12 & 9.8 & 0.07 & 0.07 & 9.7 & 0.18 & 0.21 & 28.5 \\
\hline Orissa & 6.11 & 7.1 & 0.61 & 5.3 & 0.02 & 0.03 & 3.4 & 0.08 & 0.09 & 12.6 \\
\hline Assam & 3.65 & 4.3 & 0.59 & 5.2 & 0.02 & 0.03 & 3.3 & 0.08 & 0.09 & 12.5 \\
\hline Tamil Nadu & 4.52 & 5.3 & 0.49 & 4.3 & 0.01 & 0.01 & 1.6 & 0.04 & 0.06 & 8.4 \\
\hline Bihar & 4.2 & 4.9 & 0.17 & 1.7 & 0.02 & 0.01 & 0.1 & 0.02 & 0.03 & 3.5 \\
\hline Kerala & 0.64 & 0.1 & 0.09 & 0.1 & 0.01 & 0.01 & 0.1 & 0.01 & 0.01 & 1.5 \\
\hline Maharashtra & 2.51 & 2.9 & 0.07 & 0.1 & 0.01 & 0.01 & 0.1 & 0.01 & 0.01 & 1.3 \\
\hline Uttar Pradesh & 11.2 & 13.1 & 0.01 & 0.1 & 0.01 & 0.01 & 0.1 & 0.01 & 0.01 & 0.1 \\
\hline Others (7 states) & 23.84 & 27.9 & 0.46 & 4 & 0.03 & 0.03 & 4.2 & 0.07 & 0.08 & 10.9 \\
\hline Total & 85.67 & 100 & 11.71 & 100 & 0.63 & 0.64 & 86.1 & 1.66 & 2.06 & 276.4 \\
\hline
\end{tabular}

and rice in 2020 in China, Japan, and South Korea from 1 to $9 \%$ in 1990 by Wang and Mauzerall (2004). Further, Zhu et al. (2011) reported that the response of RYL of winter wheat to $\mathrm{O}_{3}$ concentration is similar in China, Europe, and India in an OTC study indicates that the increasing $\mathrm{O}_{3}$ is the rising threat to wheat production.

The estimated rabi rice $R Y L$ is $5 \%$ (14\%) using the $M 7$ (AOT40) index is in agreement with the losses in rice yield is $10-15 \%$ at 40-70 ppbv $\mathrm{O}_{3}$ concentration in an OTC study in Varanasi, India reported by Rai et al. (2010). Our estimate for rabi rice losses in this study is similar to the RYL for rice is $6 \%$ during summer season using AOT40 index in north India (Ghude et al. 2008). Similarly, Van et al. (2009) reported that the rice grain yield loss is $10 \%$ at $32 \mathrm{ppbv}$ and $17 \%$ at 62 ppbv $\mathrm{O}_{3}$ concentration treatment in fumigation study at a periurban area of Vietnam is agree well with the our estimate of rabi rice in India.

The winter wheat and rabi rice RYL is 5-11 (6-30\%) and 3-6\% (12-16\%), respectively, based on M7 (AOT40) index in this study. The global studies performed by Van Dingenen et al. (2009) reported that winter wheat (rice) RYL is 13 and $28 \%$ (6 and $8 \%$ ) using the M7 and AOT40 indices, respectively, over the India is well agree with the estimated winter wheat (rice) RYL in this study. Avnery et al. (2011a) estimate winter wheat RYL is $8 \%(27 \%)$ using the M7 (AOT40) index over the India is in good agreement with the estimate of winter wheat RYL in this study.

Table 5 shows the summary of winter wheat CPL and ECL estimated in this study is compared with studies available for India on global scale. The winter wheat CPL is 9 and $29 \mathrm{Mt}$ (associated ECL is 1,222 and 4,091 million US\$, mean ECL 2,657 million US\$) using M7 and AOT40 indices, respectively, annually in this study are in good agreement with earlier estimate for winter wheat CPL is 12 and $29 \mathrm{Mt}$ (associated ECL is 1,711 and 4,310 million US\$, mean ECL 3,011 million US\$ for the year 2000) for India reported by Van Dingenen et al. (2009). Similarly, winter wheat CPL is 8 and $25 \mathrm{Mt}$ (associated ECL is 1,212 and 3,788 million US\$, mean ECL 2,500 million US\$ for the year 2000) using M7 and AOT40 indices, respectively, over India reported by Avnery et al. (2011a) is agreed well with the winter wheat CPL and ECL is estimated in this study.

We estimate rabi rice CPL is $0.64 \mathrm{Mt}(2 \mathrm{Mt})$ and associated ECL is 86 million US\$ (276 million US\$) using the M7

Table 5 Summary and comparison of estimated winter wheat crop production loss (CPL) and associated economic cost loss (ECL) per year in India using M7 and AOT40 indices for the period 2002-2007

\begin{tabular}{|c|c|c|c|c|c|c|}
\hline \multicolumn{3}{|l|}{ CPL } & \multicolumn{3}{|l|}{ ECL } & \multirow[t]{2}{*}{ Reference } \\
\hline M7 & AOT40 & Mean & M7 & AOT40 & Mean & \\
\hline 8.6 & 28.8 & 18.7 & 1,222 & 4,091 & 2,657 & Present study \\
\hline 11.6 & 29.1 & 20.4 & 1,711 & 4,310 & 3,011 & Van Dingenen et al. (2009) \\
\hline 8 & 25 & 16.5 & 1,212 & 3,788 & 2,500 & Avnery et al. (2011a, b) \\
\hline
\end{tabular}

Winter wheat CPL is in million metric tons, and ECL in million US dollars 
(AOT40) index per annum for the study period. The estimated rabi rice losses in this study is not compared with the total rice (kharif plus rabi rice) losses (8-11 Mt) estimated using the M7 and AOT40 indices over India by Van Dingenen et al. (2009), as we estimate only rabi rice losses. We expect high critical limit $12.8 \mathrm{ppm} \mathrm{h}$ is not exceeding during the rainy season in India. Available $\mathrm{O}_{3}$ studies in India shows the measured seasonal diurnal variations of maximum $\mathrm{O}_{3}$ concentration is less than $30 \mathrm{ppbv}$ during the monsoon season (JuneSeptember; kharif rice season) over the Indian region (Satsangi et al. 2004; Ahammed et al. 2006; Beig et al. 2007; Reddy et al. 2008; Debaje and Kakade 2009; Purkait et al. 2009; Debaje et al. 2010; Kumar et al. 2010; Singla et al. 2011; Mahapatra et al. 2012; David and Nair 2011; Nishanth et al. 2012; Elampari et al. 2013).

As Asian (including Indian) cultivars (wheat and rice) are more sensitive to $\mathrm{O}_{3}$ than the western $\mathrm{CR}$ functions, that highlight crop yield losses are underestimated in Asia (Emberson et al. 2009). The winter wheat RYL increases to $20 \%$ with the increase of mean $\mathrm{O}_{3}$ concentration by $25 \%$ in the ambient environment of China reported by Zhu et al. (2011). The crop yield losses are predicted to escalate in future due to climate change and increase of $\mathrm{O}_{3}$ concentration in many areas (IPCC 2001; Oltmans et al. 2006; The Royal Society 2008; Cape 2008; Wilkinson et al. 2012; Lobell and Gourdji 2012). Indian population is growing at the rate of $1.3 \%$ per year (2012). The current India's population is 1.2 billion and projected to increase to 1.6 billion ( $40 \%$ more than it is now) in 2050 and then decline slowly to 1.5 billion in 2100 (UN 2013). To meet the food demand, the production of food grains in India needs to be increased at the rate of $6 \mathrm{Mt}$ annually (ICAR 2011). The world will need 70 to $100 \%$ more food to feed 9 billion people in 2050 than in 2006 (WDR 2008; Godfray et al. 2010; Tilman et al. 2011; WRI 2013). The projected demand for winter wheat and rabi rice (14\% of the total rice production) in India are increase to 95 and $22 \mathrm{Mt}$, respectively, in 2030 from 64 and $11 \mathrm{Mt}$ in 2000 (ICAR 2011), while it is 138 and $34 \mathrm{Mt}$ in 2050 . The winter wheat (rabi rice) RYL is $31.1 \%$ (11.3\% mean of M7 and AOT40 indices) in 2030 (Van Dingenen et al. 2009), and it is $41.8 \%$ (15.6\%) in 2050 due to increase of $\mathrm{O}_{3}$ concentration under an optimistic scenario of future $\mathrm{O}_{3}$ precursor emissions. The winter wheat (rabi rice) CPL is $51 \mathrm{Mt}(3.4 \mathrm{Mt})$ in 2030, and it is $99 \mathrm{Mt}$ (6.6 Mt) in 2050, the associated winter wheat (rabi rice) ECL is 7.2 billion US $\$_{2002-2007}\left(0.4\right.$ billion US $\$_{2002-2007}$ ) in 2030 , and it is 14 billion US $\$ 2002-2007$ ( 0.9 billion US $\$ 2002-2007)$ in 2050 due to $\mathrm{O}_{3}$-induced yield losses. The projected winter wheat CPL is $51 \mathrm{Mt}$ in 2030 in this study is comparable with estimated winter wheat CPL $56 \mathrm{Mt}$ highest in India in 2030 reported by Avnery et al. (2011b). The total monetary loss occur is 2.8 billion US\$2002-2007 per year for 2002-2007 due to winter wheat and rabi rice losses, while the losses 7.6 billion $\mathrm{US \$}_{2002-2007}$ in 2030 and 14.9 billion US\$2002-2007 in 2050.
The climate change will reduce highest agriculture crop yield by $18 \%$ in India in 2050 expected to further increase the food security problems (Wheeler and Braun 2010; WDR 2010). To feed a growing population, India will need to increase crop yield with sustainable intensification of agriculture. The winter wheat and rabi rice losses is estimated in this study should be view cautiously because of limited $\mathrm{O}_{3}$ data over the Indian region. Our results suggest that future winter wheat and rabi rice yield losses due to $\mathrm{O}_{3}$ damage will be large, if no mitigation efforts for curbing the $\mathrm{O}_{3}$ precursor emissions (particularly $\mathrm{NO}_{\mathrm{x}}$ ) are effectively implemented in India.

\section{Conclusions}

In this study, we estimated India's risk to two major crops (winter wheat and rabi rice) of $\mathrm{O}_{3}$ pollution using measured $\mathrm{O}_{3}$ concentration and two indices (M7 and AOT40) of $\mathrm{O}_{3}$ exposure, field-based CR relationships. The estimated winter wheat and rabi rice RYL was 5-11 (6-30\%) and 3-6\% (12$16 \%$ ) of the total production of winter wheat $81 \mathrm{Mt}$ and rabi rice $12 \mathrm{Mt}$, respectively, according to M7 (AOT40) index per annum for the period 2002-2007. The average winter wheat and rabi rice RYL was $9(21 \%)$ and $5 \%$ (14\%), respectively, estimated using the M7 (AOT40) index. The estimated winter wheat and rabi rice CPL was $9(29 \mathrm{Mt})$ and $0.64 \mathrm{Mt}(2 \mathrm{Mt})$ and associated ECL was 1,222 (4,091 million US\$) and 86 (276 million US\$), respectively, using M7 (AOT40) index annually. The wheat and rice are the main staple crops of the Indian people posing at high risk due to increasing $\mathrm{O}_{3}$ pollution. The M7 and AOT40 indices values are suggested that agricultural crops production in India is potentially at high risk from increasing $\mathrm{O}_{3}$ concentration indicated that the rise in anthropogenic pollution in the urban and rural areas.

Acknowledgments We are thankful to the Director of the Indian Institute of Tropical Meteorology, Pune for encouragement to carry out this study. The comments and suggestions of reviewers have substantially improved the quality of the paper.

Open Access This article is distributed under the terms of the Creative Commons Attribution License which permits any use, distribution, and reproduction in any medium, provided the original author(s) and the source are credited.

\section{References}

Agrawal M (2003) Air pollution impact on vegetation in India. In: Emberson LD, Ashmore MR, Murray F (eds) Air pollution impacts on crops and forests: a global assessment. Imperial College Press, London, pp 165-187

Ahammed YN, Reddy RR, Gopal KR et al (2006) Seasonal variation of the surface ozone and its precursor gases during 2001-2003, measured at Anantapur $\left(14.62^{\circ} \mathrm{N}\right)$, a semi-arid site in India. Atmos Res $80: 151-164$ 
Amann M, Derwent D, Forsberg B, Hanninen O, Hurley F, Krzyzanowski M, de Leeuw F, Liu SJ, Mandin C, Schneider J, Schwarze P, Simpsonet D (2008) Health risks of ozone from longrange transboundary air pollution WHO: World Health Organization, Europe

Avnery S, Mauzerall DL, Liu J, Horowitz LW (2011a) Global crop yield reductions due to surface ozone exposure: 1 . Year 2000 crop production losses and economic damage. Atmos Environ 45:2284 2296

Avnery S, Mauzerall DL, Liu J, Horowitz LW (2011b) Global crop yield reductions due to surface ozone exposure: 2. Year 2030 crop production losses and economic damage under two scenarios of $\mathrm{O}_{3}$ pollution. Atmos Environ 45:2297-2309

Beig G, Gunthe S, Jadhav DB (2007) Simultanous measurements of ozone and its precursors on a diurnal scale at a semi urban site in India. J Atmos Chem 57:239-253

Berntsen T, Isaksen ISA, Wang W, Liang X (1996) Impacts of increased anthropogenic emissions in Asia on tropospheric ozone and climate. Tellus 48B:13-32

Booker F, Muntifering R, McGrath M et al (2009) The ozone components of global change: potential effects on agriculture and horticulture plant yield, product quality and interactions with invasive species. $\mathrm{J}$ Integr Plant Biol 51(4):337-351

Commission for Agriculture Costs and Prices (CACP) (2012) Price policy for kharif crops. Department of Agriculture and Cooperation, Ministry of Agriculture, Government of India, New Delhi

Cape JN (2008) Surface ozone concentrations and ecosystem health: past trends and a guide to future projections. Sci Total Environ 400:257269

Carmichael GR et al (2003) Measurements of sulfur dioxide, ozone and ammonia concentrations in Asia, Africa, south America using passive samplers. Atmos Environ 37(9-10):1293-1308

Chameides WL, Xingsheng L, Xiaoyan T et al (1999) Is ozone pollution affecting crop yields in China? Geophys Res Lett 26:867-870

David LM, Nair PR (2011) Diurnal and seasonal variability of surface ozone and NOx at a tropical coastal site: association with mesoscale and synoptic meteorological conditions. J Geophys Res. doi:10. 1029/2010JD015076

Deb Roy S, Beig G, Ghude S (2009) Exposure-plant response of ambient ozone over the tropical Indian region. Atmos Chem Phys 9:52535260

Debaje SB, Kakade AD (2009) Surface ozone variability over western Maharashtra, India. J Hazard Mater 161:686-700

Debaje SB, Kakade AD, Johnson Jeyakumar S (2010) Air pollution effect of $\mathrm{O}_{3}$ on crop yield in rural India. J Hazard Mater 183:773-779

Directorate of Rice Development (DRD) (2007) Rice in India - a hand book of statistics. Department of Agriculture and Cooperation, Ministry of Agriculture, Government of India, Patna (Bihar)

Elampari K, Debaje SB, Johnson SJ, Chithambarathanu T (2013) Measurements of ozone and its precursor nitrogen dioxide and crop yield losses due to cumulative ozone exposure over $40 \mathrm{ppb}$ (AOT40) in rural coatal southern India. J Atmos Chem. doi:10. 1007/s10874-013-9272-7

Emberson LD, Ashmore MR, Murray F (2003) Air pollution impacts on crops and forests: a global assessment. Imperial College Press, London

Emberson LD, Buker P, Ashmore MR, Mills G, Jackson LS, Agrawal M, Atikuzzaman MD, Cinderby S, Engardt M, Jamir C, Kobayashi K, Oanh NTK, Quadir QF, Wahid A (2009) A comparison of North American and Asian exposure-response data for ozone effects on crop yields. Atmos Environ 43:1945-1953

Engardt M (2008) Modeling of near-surface ozone over South Asia. J Atmos Chem 59:61-80. doi:10.1007/s10874-008-9096-z
Felzer BS, Cronin T, Reilly JM et al (2007) Impacts of ozone on trees and crops. CR Geoscience 339:784-798

Fuhrer J (2009) Ozone risk for crops and pastures in present and future climates. Naturwissenschaften 96:173-194

Fuhrer JLS, Ashmore MR (1997) Critical levels for ozone effects on vegetation in Europe. Environ Pollut 97:91-106

Ghude SD, Jain SL, Arya BC et al (2008) Ozone in ambient air at a tropical megacity, Delhi: characteristics, trends and cumulative ozone exposure indices. J Atmos Chem 60:237-252

Godfray HCJ, Beddington JR, Crute IR et al (2010) Food security: the challenge of feeding 9 billion people. Science 327:812-818

Indian Council of Agriculture Research (ICAR) (2011) Vision 2030. Ministry of Agriculture, Government of India, New Delhi

India Meteorological Department (IMD) (2007) Rainfall data for SW monsoon 2002-2007

Intergovernmental Panel on Climate Change (IPCC) (2001) Climate change 2001: the scientific basis. Cambridge University Press, Cambridge, UK

Jain SL, Arya BC, Kumar A (2005) Observational study of surface ozone at New Delhi, India. Int J Remote Sens 26:3515-3526

Kumar R, Naja M, Venkataramani S (2010) Variations in surface ozone at Nainital: a high-altitude site in the central Himalayas. J Geophys Res 115, D16302. doi:10.1029/2009JD013715

Lelieveld J, Crutzen PJ, Ramanathan V et al (2001) The Indian Ocean experiment: widespread air pollution from south and southeast Asia. Science 291:1931-1936

Lobell DB, Field CB (2007) Global scale climate-crop yield relationships and the impact of recent warming. Environ Res Letts. doi:10.1088/ $1748-9326 / 2 / 1 / 014002$

Lobell DB, Gourdji SM (2012) The influence of climate change on global crop productivity. Plant Physiol 160:1686-1697

Mahapatra PS, Jena J, Moharana S et al (2012) Surface ozone variation at Bhubaneswar and intra-corelationship study with various parameters. J Earth Syst Sci 121(5):1163-1175

Mauzerall DL, Wang X (2001) Protecting agricultural crops from the effects of tropospheric ozone exposure-reconciling science and standard setting. Annu Rev Energy Environ 26:237-268

Mills G, Buse A, Gimeno B et al (2007) A synthesis of AOT40-based response functions and critical levels of ozone for agricultural and horticultural crops. Atmos Environ 41:2630-2643

Mittal ML, Hess PG, Jain SL, Arya BC, Sharma C (2007) Surface ozone in the Indian region. Atmos Environ 41:6572-6584

National Consortium of SRI (NCS) (2013) Transforming rice production with SRI (System of Rice Intensification) knowledge and practice. Hyderabad, Andhra Pradesh, India. www.agsri.com

Nishanth T, Satheesh Kumar MK, Valsaraj KT (2012) Variations in surface ozone and NOx at Kannur: a tropical, coastal site in India. J Atmos Chem 69:101-126

Ohara T, Akimoto H, Kurokawa J (2007) An Asian emission inventory of anthropogenic emission sources for the period 1980-2020. Atmos Chem Phys 7:4419-4444

Oltmans SJ, Lefohn AS, Harris JM, Galbally I, Scheel HE, Bodeker G, Brunke E, Claude H, Tarasick D, Johnson BJ et al (2006) Long-term changes in tropospheric ozone. Atmos Environ 40: $3156-3173$

Purkait NN, De S, Sen S (2009) Surface ozone and its precursors at two sites in the northeast coast of India. Ind J Radiol Space Phys 38:86-97

Rai R, Agrawal M, Agrawal SB (2010) Threat to food security under current levels of ground level ozone: a case study for Indian cultivars of rice. Atmos Environ 44:4272-4282

Reddy RR, Rama Gopal K, Siva Sankara Reddy L et al (2008) Measurements of surface ozone at semi-arid site Anantapur $\left(14.62^{\circ} \mathrm{N}, 77.65^{\circ} \mathrm{E}, 331 \mathrm{~m}\right.$ asl) in India. J Atmos Chem 59:47-59. doi:10.1007/s10874-008-9094-1

Satsangi GS, Lakhani A, Kulshrestha PR et al (2004) Seasonal and diurnal variation of surface ozone and a preliminary analysis of 
exceedance of its critical levels at a semi-arid site in India. J Atmos Chem 47:271-286

Singla V, Satsangi A, Pachauri T et al (2011) Ozone formation and destruction at a sub-urban site in North Central region of India. Atmos Res 101:373-385

Tang H, Takigawa M, Liu G, Zhu J, Kobayashi k (2013) A projection of ozone-induced wheat production loss in China and India for the years 2000 and 2020 with exposure-based and flux-based approaches. Glob Chang Biol 19(9):2739-2752

The Royal Society (2008) The ground-level ozone in the 21st century: future trends, impacts and policy implications. Science policy. Report 15/08. London

Tilman D, Balzer C, Hill J, Befort BL (2011) Global food demand and the sustainable intensification of agriculture. PNAS 108(50):20260 20264

UN (2013) Growing population, world population prospects: the 2012 revision. UN, New York

van Aardenne JA, Carmichael GR, Levy H II, Streets D, Hordijk L (1999) Anthropogenic NO(x) emissions in Asia in the period 1990-2020. Atmos Environ 33:633-646

Van Dingenen R, Dentener FJ, Raes F et al (2009) The global impact of ozone on agriculture crop yields under current and future air quality legislation. Atmos Environ 43:604-618

Van DTH, Ishii S, Oanh NTK (2009) Assessment of ozone effects on local rice cultivar by portable ozone fumigation system in Hanoi. Vietnam Environ Monit Assess. doi:10.1007/s10661-008-0456-6
Wahid A (2003) Air pollution impact on vegetation in Pakisthan. In: Emberson LD, Ashmore MR, Murray F (eds) Air pollution impacts on crops and forests: a global assessment. Imperial College Press, London, pp 189-213

Wang X, Mauzerall DL (2004) Characterizing distributions of surface ozone and its impact on grain production in China, Japan and South Korea: 1990 and 2020. Atmos Environ 38:4383-4402

Wang X, Zhang Q, Zheng F (2012) Effects of elevated $\mathrm{O}_{3}$ concentration on winter wheat and rice yields in the Yangtze River Delta, China. Environ Pollut 171:118-125

World Development Report (WDR) (2008) Agriculture for developments. The World Bank, Washington, DC

World Development Report (WDR) (2010) Development and climate change. The World Bank, Washington, DC

Wheeler T, Braun J (2010) Climate change impacts on global food security. Science 341:508-513

Wilkinson S, Mills G, Illidge R, Davies WJ (2012) How is ozone pollution reducing our food supply? J Exp Bot 63: $527-536$

World Resources Institute (WRI) (2013) The global food challenge explained in 18 graphics. www.wri.org/blog/global-foodchallenge-explained-18-graphics?utm_campaign

Zhu X, Feng Z, Sun T, Liu X, Tang H, Zhu J, Guo W, Kobayashi K (2011) Effects of elevated ozone concentration on yield of four Chinese cultivars of winter wheat under fully open-air field conditions. Glob Chang Biol 17(8):2697-2706 